\title{
Erratum zu: Handbuch Historische Narratologie
}

\section{Eva von Contzen / Stefan Tilg (Hg.)}

\section{Erratum zu: \\ Die Online-Version in: E. von Contzen/S. Tilg, Handbuch Historische Narratologie, https://doi.org/10.1007/978-3-476-04714-4}

Die Namen der Kapitelautoren wurden online korrigiert.

Dort standen anfangs überall die Namen der Herausgeber.

Die korrigierte Online-Version dieses Buches finden Sie unter https://doi.org/10.1007/978-3-476-04714-4 